\title{
Eliminating blurry bands in gels with a simple cost-effective repair to the gel cassette
}

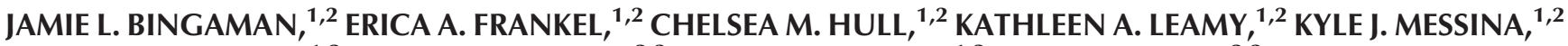 \\ DAVID MITCHELL III, ${ }^{1,2}$ HONGMARN PARK, ${ }^{2,3}$ LAURA E. RITCHEY, ${ }^{1,2}$ PAUL BABITZKE, ${ }^{2,3}$ \\ and PHILIP C. BEVILACQUA ${ }^{1,2,3}$ \\ ${ }^{1}$ Department of Chemistry, The Pennsylvania State University, University Park, Pennsylvania 16802, USA \\ ${ }^{2}$ Center for RNA Molecular Biology, The Pennsylvania State University, University Park, Pennsylvania 16802, USA \\ ${ }^{3}$ Department of Biochemistry and Molecular Biology, Pennsylvania State University, University Park, Pennsylvania 16802, USA
}

\begin{abstract}
Gel electrophoresis and subsequent imaging using phosphorimagers is one of the most important and widely used techniques in RNA and DNA analysis. Radiolabeling nucleic acids with ${ }^{32} \mathrm{P}$ and detecting bands using a phoshorimager are useful both in a qualitative sense for nucleic acid detection and in a quantitative sense for structural, kinetic, or binding-based assays. Because of this, good resolution of gel bands based on molecular weight and size of RNA or DNA is essential for analysis. The appearance of blurry gel bands of ${ }^{32} \mathrm{P}$-labeled RNA and DNA thus represents a serious problem in the laboratory. A quick search on the Internet uncovers numerous reports begrudging the appearance of blurry bands, as well as attempts to fix them without success. Indeed, our laboratories were beset by the intermittent problem of blurry gels for over one year before we found a solution. Herein we describe a simple and cost-effective solution to a problem that we show originates from the phosphorimager cassettes rather than the integrity of the gel itself. We hope that the information provided here will lead to immediate help for other laboratories experiencing similar issues with labeled nucleic acid gel-based assays. The improvement in the clarity of the gels is nothing short of astonishing in many instances and will lead to higher resolution images for analysis and publications.
\end{abstract}

Keywords: gel electrophoresis; methods; PAGE

There are many variables that can potentially affect gel resolution, including quality of gel stocks, polymerization time, gel paper, and gel dryers, and much of this has been described elsewhere (Rio et al. 2010). However, we found that the integrity of the phosphorimager cassettes themselves makes the largest impact on gel clarity. Here, we describe ways to remedy defective cassettes.

Phosphorimager cassettes are composed of two parts, a base onto which gels are applied and the cover phosphor screen. The base of the cassette consists of a plastic grid that is adhered to a spongy foam layer underneath. New cassettes have foam that is firm, pressing gels that lay on the plastic grid upwards so they fit snugly against the phosphor screen. As time progresses, we have found that the foam backing can deteriorate, deflate, and even crumble. This leads to gels not laying flush with the phosphor screen. Under these circumstances, $\beta$-emissions from the radiolabeled RNA or DNA, which travel in all directions, result in large swaths on the screen. When scanned, this leads to blurry bands

Corresponding authors: pxb28@psu.edu,pcb5@psu.edu

Article published online ahead of print. Article and publication date are at http://www.rnajournal.org/cgi/doi/10.1261/rna.059303.116. that in many cases have been incorrectly attributed to poor polymerization, salty samples, or incomplete drying.

Replacing the screen and defective cassette can cost over $\$ 3000$ per unit. However, simply replacing the foam backing alone with a stiff foam core, as illustrated in Figure 1, eliminated this diffusion in our hands. Foam core boards (32 in $\times$ 40 in $\times 3 / 16$ in) were purchased from a local art supply store for fewer than ten dollars each. The foam core was cut to size and then placed on top of the deteriorated foam in the cassette base. (The user can scrape out the old foam and replace it with sheets of Whatman paper for spacing if desired, but we chose to leave the foam in for extra filling and ease of repair.) The plastic grid was placed back on top of the foam core and then taped into place. The screen was then placed back on top of the cassette and the latch closed. Some adjustment of the latches may be necessary to achieve a snug, secure fit. Remarkably, as shown in Figure 2, we were able to take the

(C) 2016 Bingaman et al. This article is distributed exclusively by the RNA Society for the first 12 months after the full-issue publication date (see http://rnajournal.cshlp.org/site/misc/terms.xhtml). After 12 months, it is available under a Creative Commons License (Attribution-NonCommercial 4.0 International), as described at http://creativecommons.org/licenses/ by-nc/4.0/. 

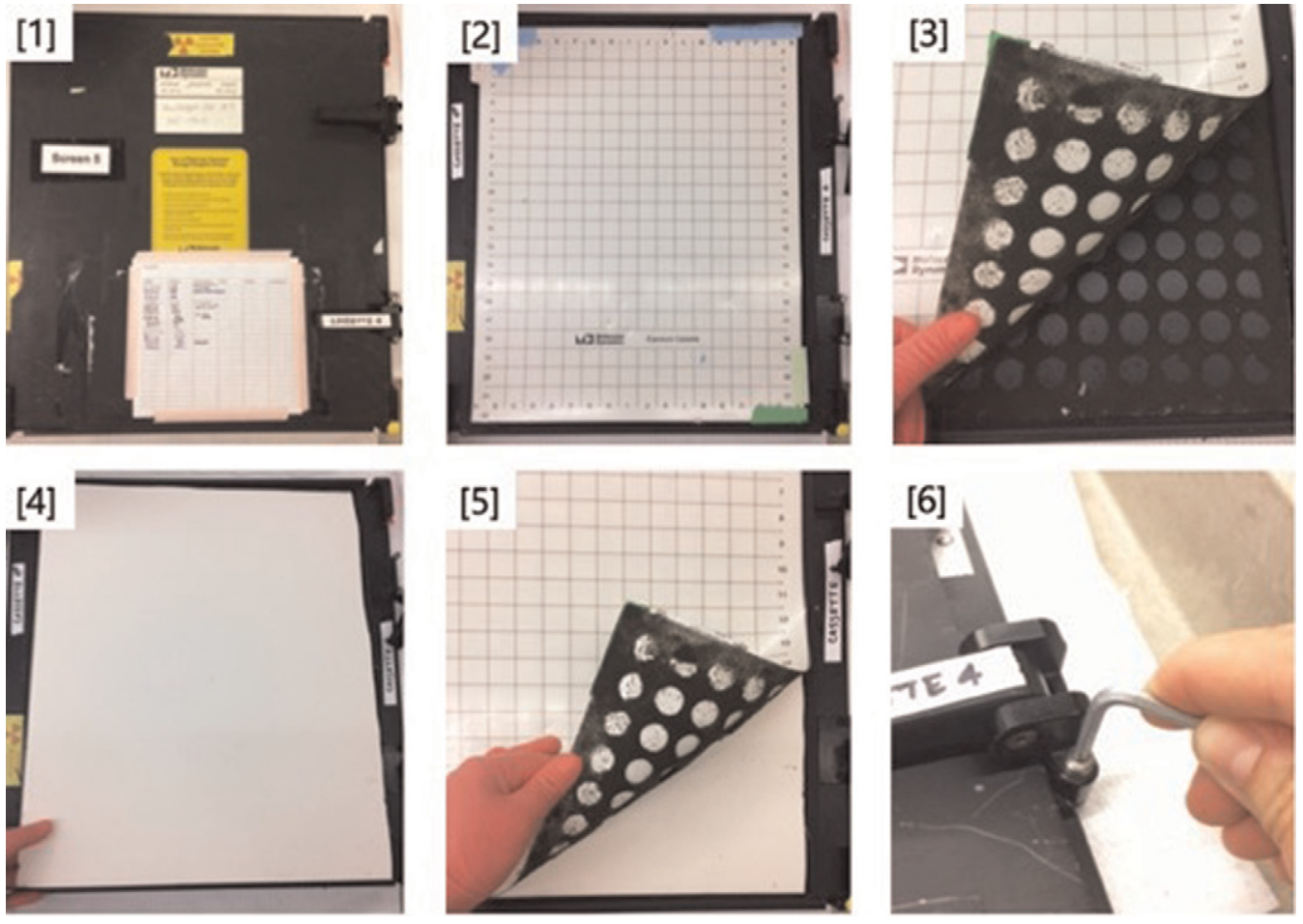

FIGURE 1. Schematic for replacing defective foam in phosphorimager cassettes. (1) Identify defective cassette, i.e., one that has resulted in blurry gels. (2) Open cassette to reveal plastic grid backing and phosphor screen (not shown). Set phosphor screen aside and work on grid backing piece only (shown). (3) Manually remove plastic grid to reveal deteriorated foam backing. (4) Cut and fit a piece of Elmer's brand foam core to the correct size for the phosphor screen. Place directly over deteriorated foam. (5) Replace plastic grid and tape into place with general-purpose laboratory tape along the edges. (6) Place phosphor screen on top of plastic grid and latch close. Adjust latch closure with an Allen wrench to achieve a tight fit.

exact same gel that previously gave blurry bands and re-expose it in the same cassette where the foam core was replaced, and obtain sharp, interpretable bands.

We believe that this is a problem hindering numerous laboratories. The quick and efficient remedy provided herein avoids the cost of purchasing a new cassette as well as a lot of time and major grief in the laboratory.

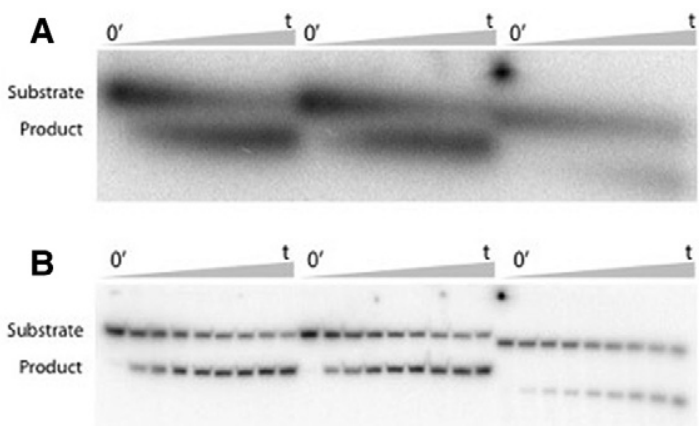

FIGURE 2. Denaturing polyacrylamide gels depicting kinetic time courses of a 5'-end radiolabeled ribozyme. (A) Gel exposed in cassette with defective foam backing. Bands of resulting image are blurred and cannot be quantified. (B) Exact same gel shown in Figure 2A, exposed on the same cassette but with a new foam core backing. Bands appear crisp and can be easily quantified.

\section{ACKNOWLEDGMENTS}

We thank the National Institutes of Health (R01-GM110237), National Science Foundation (IOS-1339282; CHE-1213667), and National Aeronautics and Space Admistration (NNX13AI01G) for support, and Dana Danielson for encouragement to write this article.

Author contributions: All authors contributed to testing hypotheses, solving issues with blurred bands, and writing the manuscript. All noncorresponding authors are listed alphabetically. E.A.F. wrote the initial draft of the manuscript.

Received September 20, 2016; accepted September 22, 2016.

\section{REFERENCES}

Rio DC, Ares M, Hannon GJ, Nilsen TW. 2010. Polyacrylamide gel electrophoresis of RNA. Cold Spring Harb Protoc doi: 10.1101/pdb. prot5444. 

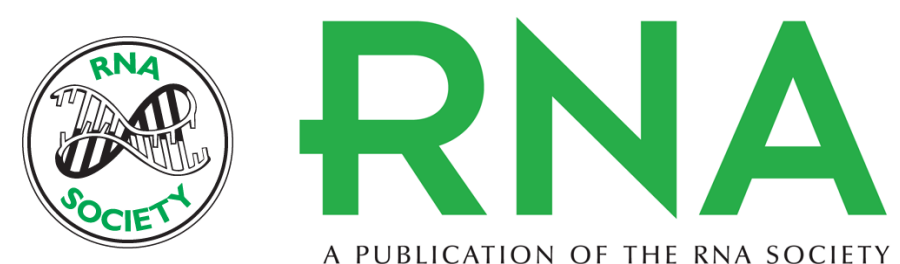

A PUBLICATION OF THE RNA SOCIETY

\section{Eliminating blurry bands in gels with a simple cost-effective repair to the gel cassette}

Jamie L. Bingaman, Erica A. Frankel, Chelsea M. Hull, et al.

RNA 2016 22: 1929-1930 originally published online October 19, 2016

Access the most recent version at doi:10.1261/rna.059303.116

\section{References This article cites 1 articles, 1 of which can be accessed free at: http://rnajournal.cshlp.org/content/22/12/1929.full.html\#ref-list-1 \\ Creative This article is distributed exclusively by the RNA Society for the first 12 months after the Commons full-issue publication date (see http://rnajournal.cshlp.org/site/misc/terms.xhtml). After 12 License months, it is available under a Creative Commons License (Attribution-NonCommercial 4.0 International), as described at http://creativecommons.org/licenses/by-nc/4.0/.}

Email Alerting Receive free email alerts when new articles cite this article - sign up in the box at the Service top right corner of the article or click here.

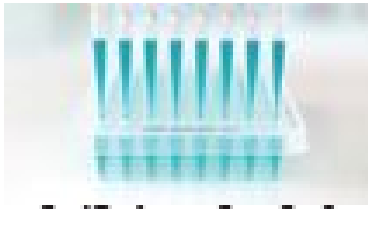

\section{Providing Precise Solutions for} your research.

To subscribe to RNA go to:

http://rnajournal.cshlp.org/subscriptions 